\title{
Cramond Roman Fort: evidence from excavations at Cramond Kirk Hall, 1998 and 2001
}

\author{
by Paul Masser* \\ with contributions by Jeremy Evans, Mhairi Hastie \\ and Fraser Hunter
}

*Headland Archaeology, 13 Jane Street, Edinburgh EH6 5HE

Scottish Archaeological Internet Report 20, 2006 www.sair.org.uk 
Published by the Society of Antiquaries of Scotland, www.socantscot.org.uk with Historic Scotland, www.historic-scotland.gov.uk and the Council for British Archaeology, www.britarch.ac.uk

Editor Debra Barrie

Produced by Archetype Information Technology Ltd, www.archetype-it.com

ISBN: $090390389 \mathrm{X}$

ISSN: $1473-3803$

Requests for permission to reproduce material from a SAIR report should be sent to the Director of the Society of Antiquaries of Scotland, as well as to the author, illustrator, photographer or other copyright holder.

Copyright in any of the Scottish Archaeological Internet Reports series rests with the SAIR Consortium and the individual authors.

The maps are reproduced from Ordnance Survey material with the permission of Ordnance Survey on behalf of The Controller of Her Majesty's Stationery Office. CCrown copyright 2001. Any unauthorized reproduction infringes Crown copyright and may lead to prosecution or civil proceedings. Historic Scotland Licence No GD 03032G, 2002.

The consent does not extend to copying for general distribution, advertising or promotional purposes, the creation of new collective works or resale. 


\section{Contents}

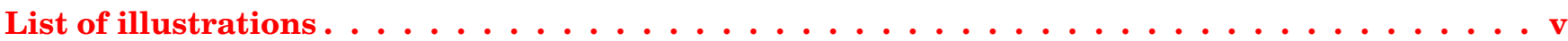

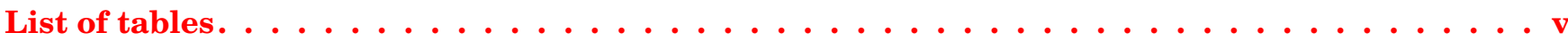

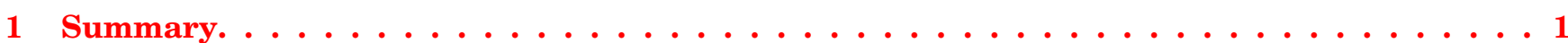

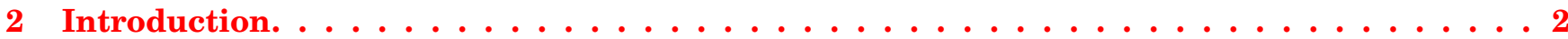

3 Existing Evidence for the Layout and History of the Fort . . . . . . . . . . . . . . . . 3

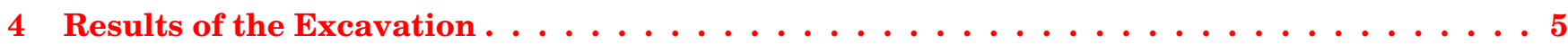

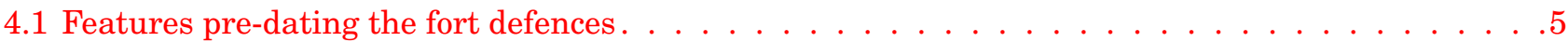

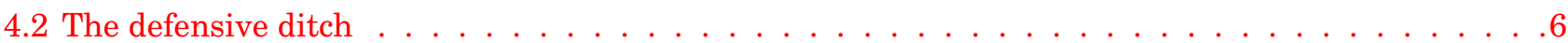

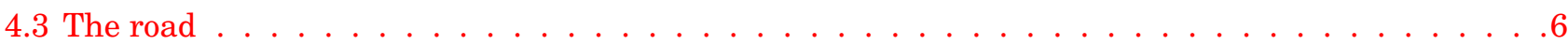

4.4 Later developments: disuse of the ditch and encroachment of the extramural settlement. . . . . . .6

5 The Pottery by Jeremy Evans with contributions by Margaret Ward and D F Williams . . . . . . 8

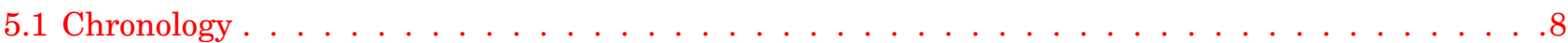

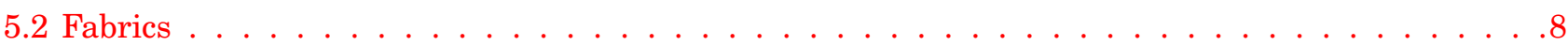

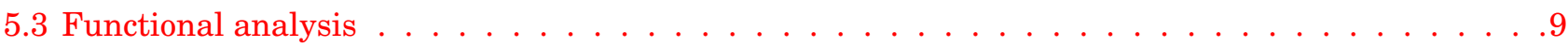

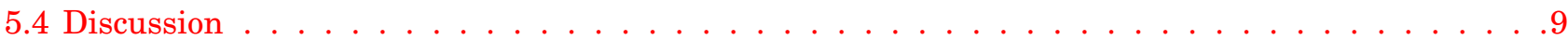

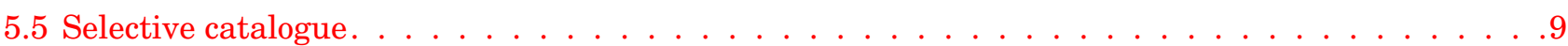

6 Other Finds by Fraser Hunter . . . . . . . . . . . . . . . . . . . . . 11

6.1 Iron objects . . . . . . . . . . . . . . . . . . . . . . . . . 11

6.1 .1 Fittings and fastenings $\ldots \ldots \ldots \ldots \ldots \ldots$

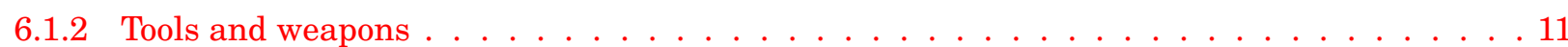

6.1 .3 Unidentified . . . . . . . . . . . . . . . . . . . . . . . 11

6.1 .4 Nails . . . . . . . . . . . . . . . . . . . . . . . . 11

6.1 .5 Hobnails and tacks. . . . . . . . . . . . . . . . . . . . . . . 11

6.2 Copper-alloy objects . . . . . . . . . . . . . . . . . . . . . . . . 11

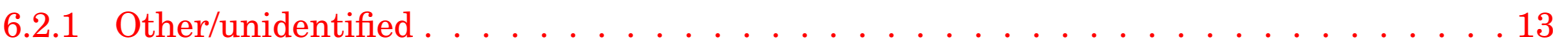

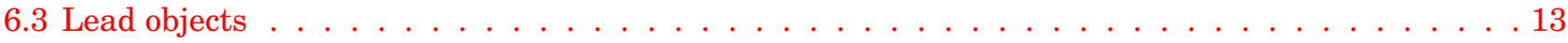

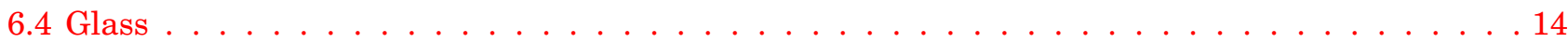

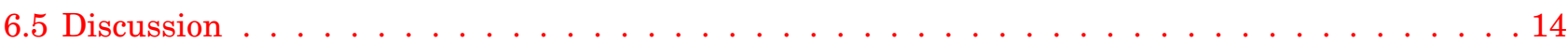

7 Plant Remains by Mhairi Hastie . . . . . . . . . . . . . . . . . . . . .15

7.1 Methodology . . . . . . . . . . . . . . . . . . . . . . . . . 15

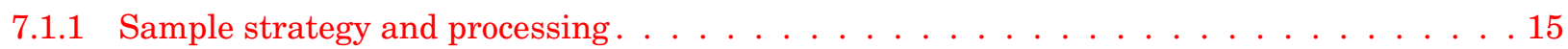

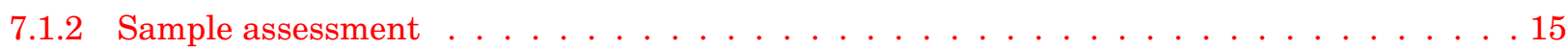

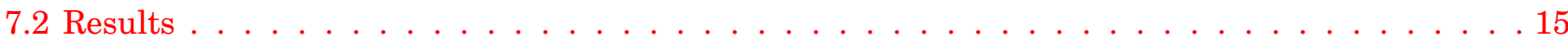




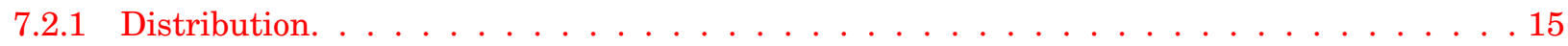

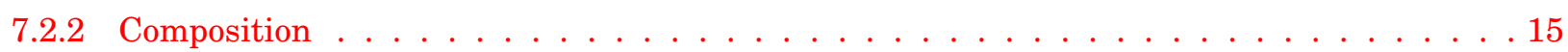

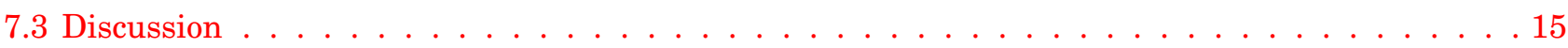

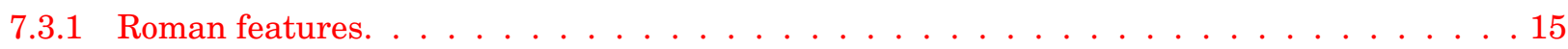

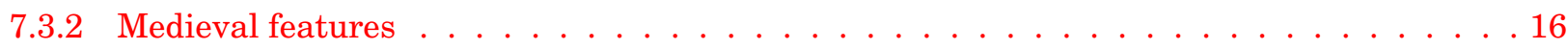

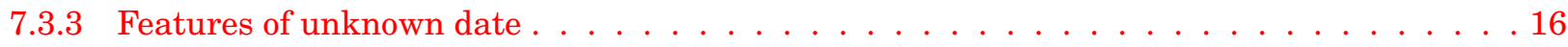

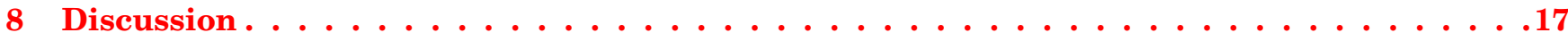

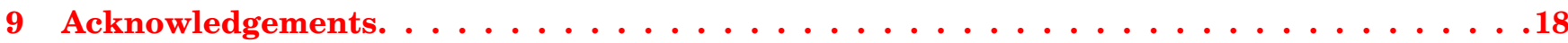

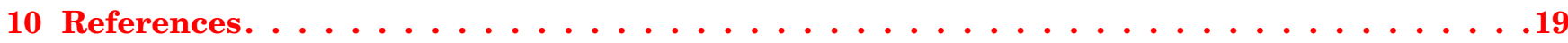




\section{List of illustrations}

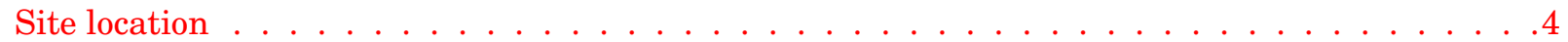

Cramond Kirk Hall: site plan . . . . . . . . . . . . . . . . . . . . . . . . 5

Pottery objects . . . . . . . . . . . . . . . . . . . . . . 10

Iron objects . . . . . . . . . . . . . . . . . . . . . . . . . . 12

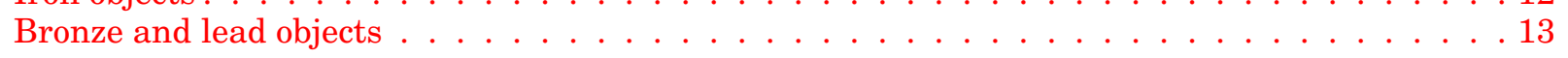

\section{List of tables}

$1 \quad$ Fabric proportions in the total Cramond Kirk Hall assemblage . . . . . . . . . . . . . . . .8

2 Cramond Kirk Hall small finds assemblage by feature and inferred function . . . . . . . . . . 14 



\section{Summary}

Excavation on the site of an extension to Cramond Kirk Hall has provided new evidence for the layout of the defences of the Roman fort, the route of the road immediately beyond it and for the phases of Roman military occupation at Cramond postulated by previous excavators. The features encountered included a broad right-angled ditch, possibly part of the outer defences, turning at this point to run parallel with the road into the fort. Three much slighter parallel ditches or gullies at the south end of the site are tentatively identified as drainage features beside the Roman road which, on this interpretation, would lie just beyond the limit of excavation At a later date, the ditch had been allowed to silt up and features including pits and a stone box-drain were cut on a different alignment, through the fill of the earlier ditch; a well was also cut across two of the roadside ditches. These later features appear to represent encroachment of extramural settlement on the defences during the Severan occupation, at a time when a large defended annexe had been constructed to the east of the fort. 
Construction of an extension to the Kirk Hall at Cramond, Edinburgh (NGR: NT 1907 7685), required Scheduled Monument Consent, as the Kirk Hall lies within the scheduled area of Cramond Roman fort. Consent for the building works was granted by Historic Scotland on condition of a programme of archaeological excavation on the affected area. An evaluation carried out by Headland Archaeology in October 1998 (Terry 1998) comprised excavation of three trenches adjacent to the Kirk Hall. A trench on the east side revealed a ditch of Roman date, while in one of the trenches to the west of the building part of a cobbled surface, possibly the Roman road leading to the fort, was identified. Full excavation of the footprint of the proposed extension was therefore necessary and this work was carried out by Headland Archaeology in January 2001 (Dalland 2001).

A mechanical excavator was used to remove up to $1.1 \mathrm{~m}$ of modern overburden, consisting of soil mixed with modern building rubble, revealing features cut into the underlying gravel subsoil. The layer of modern disturbance immediately overlay the subsoil, indicating that some recent truncation of the features may have occurred. 


\section{Existing Evidence for the Layout and History of the Fort (illus 1)}

Rae \& Rae established the line of the ramparts as shown on illustration 1 (Rae \& Rae 1974), excavating sections on the north, east and south sides where they identified a clay rampart faced with a stone wall. They also excavated buildings facing onto the via principalis within the principia and praetentura of the fort, and located the roads entering the fort to the north and south. Two defensive ditches outside the ramparts were first identified on the east side of the fort in excavations in the Manse Garden (Holmes 2003, 3-9), the inner one of which was found to continue beyond the north-east corner of the fort. The continuation of the inner ditch to the north could be interpreted as evidence that the ramparts had enclosed a larger area on the north side at one time, but alternatively could represent an annexe to the fort. A trench had been excavated by Rae \& Rae within the Manse Garden which 'extended to $50 \mathrm{ft}$ outside the rampart: showing a cobbled surface $15 \mathrm{ft}$ wide immediately outside, but no sign of a ditch', a finding which is difficult to reconcile with the results of later excavations in the Manse Garden (Rae \& Rae 1974, 172). Holmes suggests that the atypical rampart construction and cobbled surface found in this trench represent the base of a tower and the road surface within a gateway, leading out of the fort from the via quintana (Holmes 2003, 147). In the absence of a detailed plan of the Raes' trench, it is difficult to assess this reinterpretation, but a gateway in this location would be a highly unusual feature in a
Roman fort; moreover, the description implies that the cobbled surface extended right across the trench, which would accord better with a road running along the berm outside the rampart as seen, for instance, at Rough Castle (MacIvor et al. 1980, 234-5, 237). No such road was found in the later excavations, however, and the contrasting findings of the two excavations remain difficult to explain.

There is evidence from a number of locations for an annexe enclosing an extensive extramural settlement to the east of the fort. Recent excavations by AOC Archaeology Group at the Cramond Campus site have located a gateway in the eastern defences of the annexe (Hunter 2004, 269), and a ditch on an east/west alignment in the grounds of Cramond Tower (Holmes 2003, 3) may mark its north side. Part of the annexe, to the south-east of the fort, was occupied by military-associated industrial activities in the early third century. On its abandonment, this industrial area had been covered by extensive dumps of second-century refuse (Holmes 2003, 28-33, 152-3), which presumably derived from middens, associated with a long-established settlement nearby.

Set in the context of the fort layout, as reconstructed from previous archaeological work, the area excavated in 2001 lies outside the porta principalis dexter, just beyond the outer defensive ditch. In this location, evidence for the road and extramural settlement activity is to be expected. 


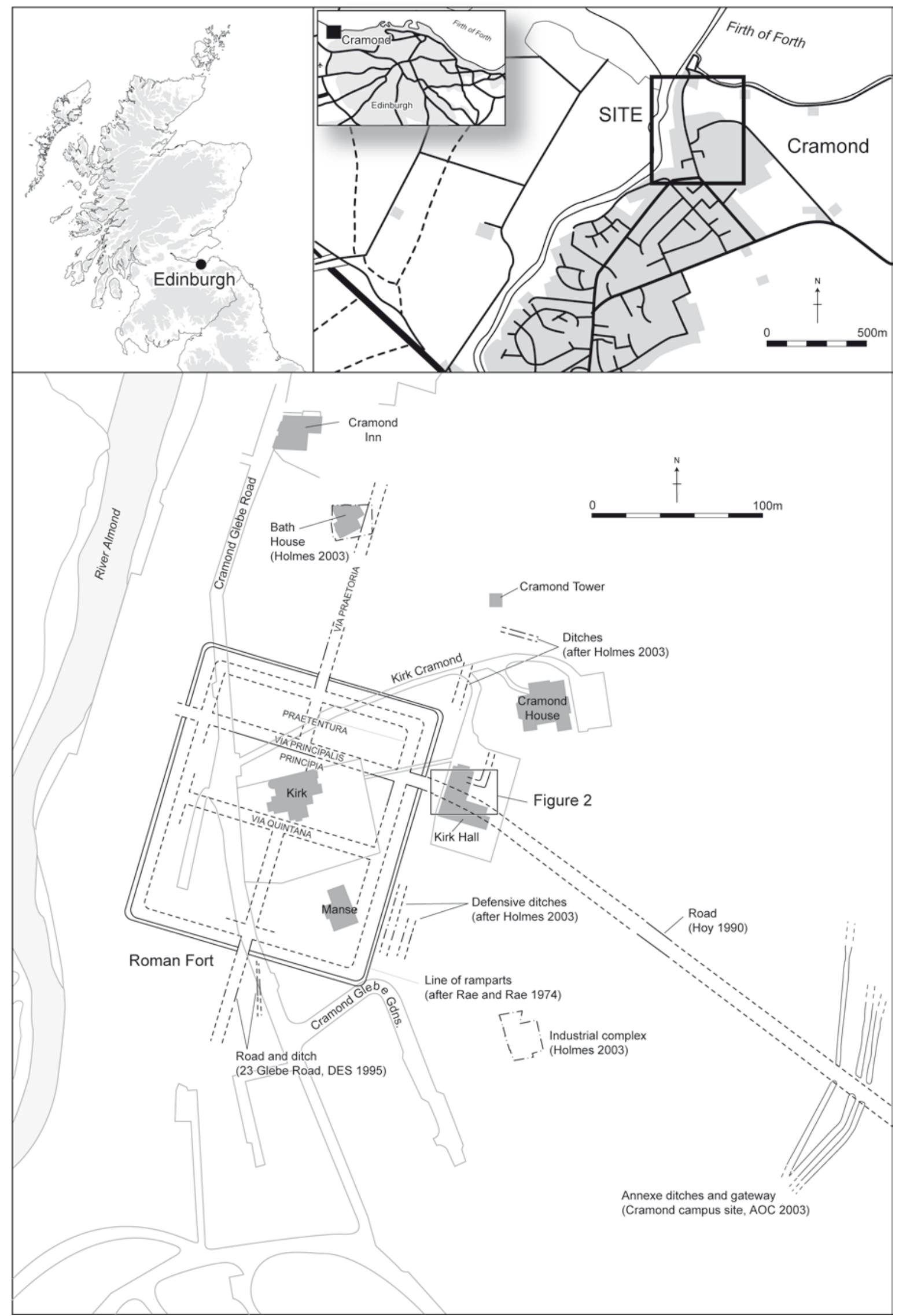

Illus 1 Site location 


\section{Results of the Excavation (illus 2)}

\subsection{Features pre-dating the fort defences}

Two ditches - context 006 (the ditch identified in the evaluation) and context 044 - appear to represent an early phase of activity, pre-dating the defensive ditch (context 031) and the roadside ditches (contexts 010, 012 and 042). Ditch 006 was up to $1.0 \mathrm{~m}$ wide and $0.3 \mathrm{~m}$ deep. Its relationship to Ditch
031 could not be clearly discerned, but the fact that Ditch 006 was not observed to cut the later drain (context 016) rules out the possibility (suggested by its shared alignment with linear Feature 030 and the modern drain cutting across the site) that Ditch 006 might be stratigraphically late. It could not be seen continuing to the north-west beyond Ditch 031. Ditch 044 was parallel with Ditch 006

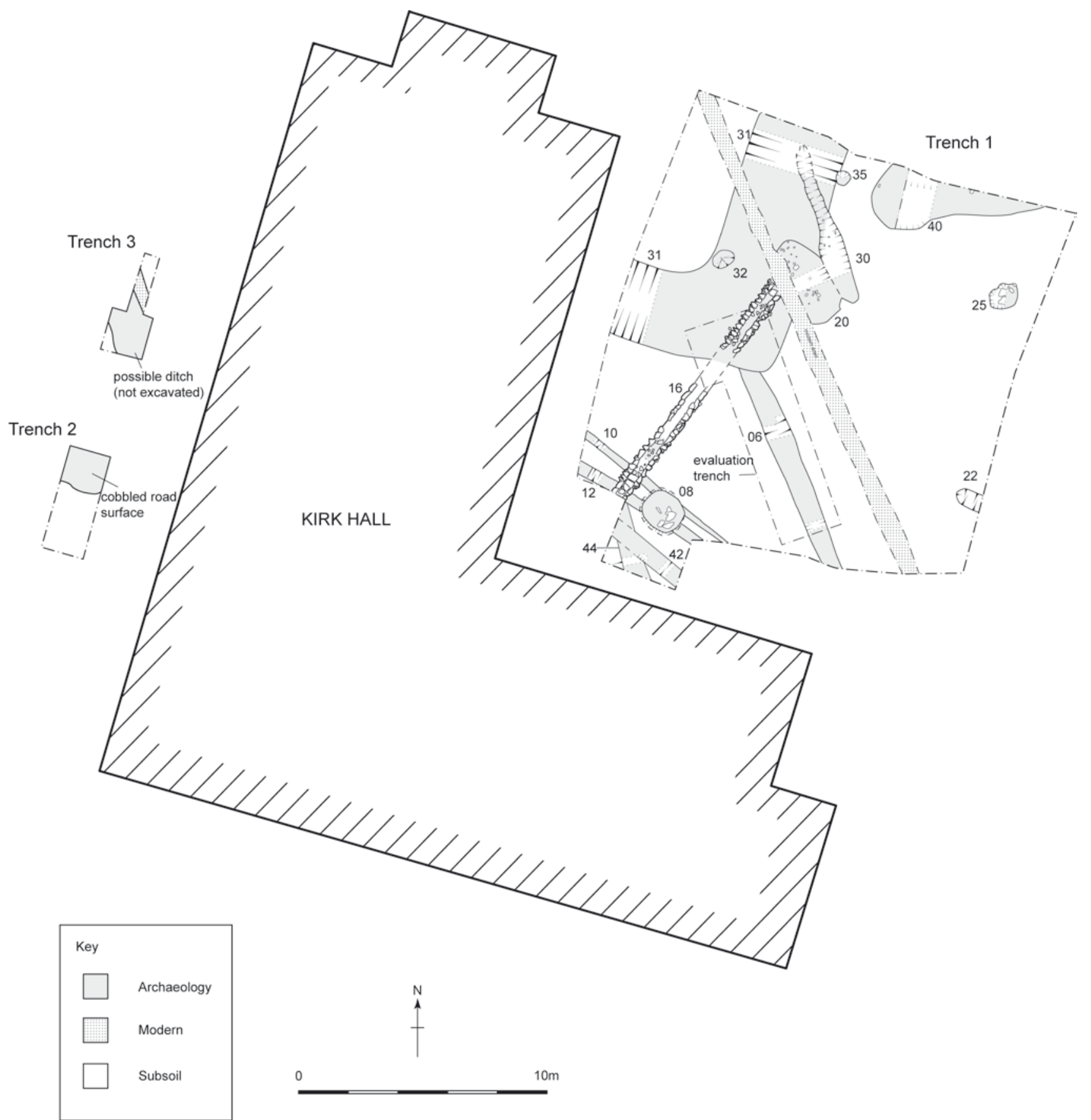

Illus 2 Cramond Kirk Hall: site plan 
and had similar dimensions. It also appears to be an early feature, as it was cut by Ditch 042, the southernmost of the roadside ditches, and by Drain 016. It could be traced for less than $3 \mathrm{~m}$, and did not continue to the north-west of Drain 016.

These ditches are on a different alignment to the fort defences, and cut across the projected line of the road, suggesting that they are unrelated to the fort. However, a sherd of amphora was recovered from the fill of Ditch 006 during the evaluation, confirming a Roman, rather than prehistoric, date. The character of this early activity is unclear, given the small area available for investigation and the slight nature of the evidence.

\subsection{The defensive ditch}

Ditch 031 is interpreted as part of an outer line of defences around the fort, turning to the west where it flanks the road approaching the gateway, possibly looped together with the inner two ditches recorded in earlier excavations. It was up to $3.1 \mathrm{~m}$ wide and at least $0.95 \mathrm{~m}$ deep, with a fairly shallow profile; below this depth, groundwater flooding the feature made excavation impossible, and in neither of the two excavated sections was the ditch bottomed. The original shape of the ditch thus remains uncertain. The homogeneous silty fill and eroded profile observed in both sections indicate that the ditch had filled up largely due to natural silting processes, rather than deliberate backfilling.

Very little artefactual material was recovered from the ditch, but a Hadrianic/Antonine Greyware sherd from context 018 (the lower fill of the western section) and the absence of diagnostic material of third-century date, suggest that the ditch formed part of the original defences of the fort erected during the mid second century during the Antonine occupation of southern Scotland.

\subsection{The road}

A cobbled surface covered the northern half of evaluation Trench 2 to the west of the Kirk Hall. Although the surface was not investigated further, and no dating evidence was found, its location is consistent with the southern edge of the Roman road as projected east from the gate of the fort.

The road was not seen in the main excavation area to the east of the Kirk Hall. However, three parallel gullies - contexts 010, 012 and 042 - were found crossing the southern end of the area, on a slightly more south-easterly alignment to that of the via principalis within the fort. The southern gully (042) was the largest, being $0.6 \mathrm{~m}$ wide and $0.4 \mathrm{~m}$ deep, while Gullies 010 and 012 were slighter features $0.2 \mathrm{~m}$ deep. The only dating evidence from any of these gullies was an amphora sherd from the fill of Gully 042.

The Roman road running east from the fort has been recorded in two locations (Hoy 1990; Gooder 2000), which suggests that it changed direction at some point outside the fort, leading to the southeast rather than continuing the alignment of the via principalis. As the road does not appear within the excavation area to the east of the Kirk Hall, it must bend to the south-east before reaching this point. The three parallel gullies can perhaps be understood as roadside drainage ditches flanking the road, which would lie just beyond the southern limit of excavation. If this interpretation is correct, it would imply repeated re-cutting of the roadside ditches, and therefore perhaps an extended period of use for the road.

\subsection{Later developments: disuse of the ditch and encroachment of the extramural settlement}

The defensive Ditch 031 appears to have silted up naturally after it went out of use, although it is not possible to discount some deliberate backfilling. A low concentration of charred cereal grains from context 038 (the upper fill of the northern section through the ditch) suggest some sort of continuing occupation in the area at this time. A number of early third-century features cut across the filled-in ditch.

A stone-lined drain (context 016) was constructed, cutting across the upper fills of Ditch 031 and two of the roadside ditches (010 and 012). The edges were lined with irregular stone slabs, but only at the southern end of the feature was the base lined with stones. Amphora sherds were found on the base elsewhere, and may have been used as a lining. The drain was truncated at the north-east end by a modern drain and terminated in a pit (context 020). The drain was filled with a stony soil deposit (context 015), which contained large quantities of pottery, animal bone and metalwork of Severan (early thirdcentury) date. These included objects too large to have been washed into a covered drain, confirming that it must have been an open feature at the time they were deposited. The size and character of the finds assemblage from this feature could suggest deliberate dumping of refuse. Pit 020, an oval flatbottomed feature $3.5 \times 1.6 \mathrm{~m}$ wide and $0.4 \mathrm{~m}$ deep, had a lower fill of brown clayey silt and a darker upper fill with very frequent subangular stones. This was interpreted by the excavators as a soakaway for the drain, but the upper fill contained medieval as well as Roman pottery; an assemblage of charred bread/ club wheat from this deposit is also consistent with a medieval, rather than Roman, date. This does not disprove the original interpretation, as later disturbance or final backfilling of the pit may have taken place at a much later date.

A deep pit (context 008), 1.5m wide and more that $1.3 \mathrm{~m}$ deep, is interpreted as a well. It was not bottomed but was capped and preserved in situ within the development. A wooden or other organic 
lining, which has decayed, must be envisaged as no evidence of a stone lining was found. The largest and most closely datable finds assemblages from the excavation came from the top and lower fills of the well (contexts 007 and 026 ). The pottery from both deposits was Commodan or Severan, indicating that the filling of the feature post-dated the abandonment of the Antonine Wall at about AD 160.

An irregular linear feature (context 030) and a small pit (context 032) may be broadly contempo- rary with the drain and the well, as they cut the upper fill of Ditch 031, and both contained Roman pottery. The function of these features is unclear. Three other small pits (contexts 022, 025 and 035) were undated; these are just as likely to be medieval as Roman because two broad pits (contexts 020 and 040) were found to contain medieval sherds as well as residual Roman material. 


\section{The Pottery by Jeremy Evans with contributions by Margaret Ward and D F Williams}

Some 145 sherds of Roman pottery were recovered from the excavations $(6.69 \mathrm{~kg}$; Table 1$)$. This is a very small assemblage, but is just sufficient to demonstrate two periods of occupation on the site. It has been quantified following the general ware categories used by the Warwickshire Museum, Oxford Unit and this author. There are no fully quantified comparative pottery data from Cramond, the material quantified by Ford, sadly omitting data on the mortaria, amphorae and Samian Ware, which renders them of limited use (Ford 2003). The dating evidence from this site is just sufficient to demonstrate two periods of occupation. It also suggests there was a rather unusual, amphora-dominated assemblage in the vicinity, which like that from Doune (Evans, forthcoming), might reflect the rather marginal location of the site in relation to the fort.

\subsection{Chronology}

The rarity of BB1, BB2 and Samian Ware (all of the latter being from context 026) and the lack of diagnostic rimsherds result in only the two deposits in the well - contexts 007 and 026 - being closely datable. Both of these post-date the end of the Antonine Wall in $c$ AD 160 and must be of Commodan or Severan date. There is very little dating evidence from the fort ditch, a second-century mortarium fragment from context 017 and a Greyware bodysherd with acute lattice from context 018 being the only pieces of any value. These both suggest a HadrianicAntonine date range.

\subsection{Fabrics}

Dressel 20 amphora sherds of first- to third-century date amount to over $47 \%$ of the sherds by count, and a massive $86 \%$ by weight. These count figures should be compared with a usual range of up to $10 \%$ and weight figures of 30-50\% from forts. High levels of amphorae are generally associated with military sites (Evans 2001), but even so the levels here are remarkably high, and like those from the rampart back at Doune (Evans, forthcoming) might be an indication of the group coming from a liminal location in the fort. Although this is accounted for in part by the use of amphora sherds lining Drain 016, even without these the levels of amphorae would still be high. Marginal locations in forts seem to produce this sort of assemblage (Evans 2002).

Of the remainder of the pottery, the majority of sherds were of oxidized ware, most probably of local

Table 1 Fabric proportions in the total Cramond Kirk Hall assemblage

\begin{tabular}{lcccc}
\hline Fabric & $\begin{array}{c}\text { No of sherds } \\
(\%)\end{array}$ & $\begin{array}{c}\text { Weight } \\
(\boldsymbol{\%})\end{array}$ & $\begin{array}{c}\text { Minimum no } \\
\text { of rims (\%) }\end{array}$ & $\begin{array}{c}\text { Rim extent } \\
(\%)\end{array}$ \\
\hline A01 & 47.4 & 85.9 & 22 & 24 \\
B01 & 1.3 & 0.6 & 0 & 0 \\
B02 & 1.3 & 0.1 & 0 & 0 \\
M01 & 1.3 & 0.6 & 0 & 0 \\
M11 & 0.6 & 0.1 & 0 & 0 \\
O01 & 12.2 & 2.8 & 11 & 6 \\
O05 & 6.4 & 1.7 & 33 & 30 \\
O07 & 2.6 & 0.1 & 0 & 0 \\
O08 & 0.6 & 3.9 & 0 & 0 \\
R01 & 11.5 & 0.3 & 11 & 30 \\
R02 & 1.3 & 0.6 & 11 & 0 \\
R03 & 1.9 & 0.2 & 0 & 8 \\
R05 & 0.6 & 0.0 & 0 & 0 \\
R06 & 0.6 & 0.0 & 11 & 0 \\
S20 & 0.0 & - & 0 \\
S30 & 0.6 & - & - & 2 \\
Z20 Med & 1.3 & - & 9 & - \\
Z30 P Med & 6.4 & 6.690 & & 134 \\
N & 0.6 & & 0 & \\
\hline
\end{tabular}


manufacture, followed by Greywares, also probably mainly local, with very few sherds of Samian, BB1 and BB2. Mortaria from Mancetter and another, possibly local, source are represented. No colourcoated ware sherds occur. The oxidized wares include North African casserole forms, which Swan has persuasively argued represent the presence of African troops bringing with them their distinctive cuisine (Swan 1992). It is notable that oxidized wares, which seem to mainly represent third-century forms, are much more important in this small group than in the fort as a whole (Ford 2003; Table 2).

Fine wares are very poorly represented in this assemblage, at $1.9 \%$ by count. This compares with a usual figure for military sites of around $10 \%$. This seems likely to relate to the marginal location of the site like the large quantity of amphorae.

A01 Dressel 20 amphorae

B01 BB1, Dorset

B02 BB2, Thameside

001 An oxidized fabric with orange core, margins and surfaces, 'clean', with common fine silver mica $>0.1 \mathrm{~mm}$. Local

O05 An oxidized fabric with orange core, margins and bufforange surfaces, with some common fine sand $c 0.2 \mathrm{~mm}$ and some fine silver mica. Local

007 An oxidized fabric with orange-brown core, margins and surfaces, with common sand temper $c 0.1-0.2 \mathrm{~mm}$ and some $c 0.5-1 \mathrm{~mm}$, and common fine silver and gold mica. Local

008 An oxidized fabric with an orange core, margins and surfaces, with common moderate-coarse sand temper c $0.3-0.5 \mathrm{~mm}$ and occasional ironstone up to $1 \mathrm{~mm}$

M01 A white-slipped oxidized mortarium fabric with orange core and margins, with common fairly fine sand c $0.2 \mathrm{~mm}$. Trituration grits; common angular translucent quartz $2-4 \mathrm{~mm}$ and some occasional red-brown subrounded slightly micaceous sandstone $c 3-5 \mathrm{~mm}$

M11 Mancetter-Hartshill mortaria

R01 A Reduced Ware with mid grey core, margins and surfaces, 'clean' with occasional rounded black ironstone $c 0.5-2 \mathrm{~mm}$. There is also a variant with a pale grey core and dark grey slipped surfaces

R02 A Reduced Ware with mid grey core, margins and surfaces, with some common fairly fine sand $c 0.2 \mathrm{~mm}$ and occasionally up to $0.5 \mathrm{~mm}$

R03 A Reduced Ware with a mid grey core and margins and mid-dark grey surfaces, with common very fine sand $c 0.05 \mathrm{~mm}$

R05 A Reduced Ware with red-brown or dark grey core, dark grey-pale grey margins and dark grey surfaces, with common-abundant moderate sand $c 0.3 \mathrm{~mm}$

R06 A Reduced Ware with a mid grey core, margins and surfaces, fairly 'clean' with some white inclusions up to $0.5 \mathrm{~mm}$

\subsection{Functional analysis}

The numbers of rims from this assemblage are too low to produce reliable functional data, four jars, two bowls and two amphora rims being represented. It is clear from the latter two vessels that amphorae were unusually strongly represented, as it is from the fabric figures.

\subsection{Discussion}

Ford has recently published a much larger corpus of material from the fort at Cramond, which includes a number of pieces that must post-date the Severan occupation (Ford 2003, particularly fig 71, nos 252 and 253, which are of later third- to early fourthcentury date). It also includes a much larger number of pieces which sit rather unhappily in a Severan group and which might fit more happily with the above pieces (Ford 2003, fig 50, no 14 and fig 51, nos 21 and 33-6; fig 58, nos 6, 7?, 11, 12, and 13; fig 60 , nos 31 and 32; fig 61, nos 52 and 54; fig 68, no 175; fig 75, nos 1-11). The Dalesware jars could be of Severan date but all the evidence from northern England suggests they did not travel much beyond north Lincolnshire until the later third to early fourth century. Similarly, the 'native' pottery on fig 75 (from Ford 2003) is all likely to originate in the Nene Valley/Northamptonshire/Bedfordshire area and, although there is a single piece from South Shields (Bidwell \& Speak 1994, no 34) from Severan deposits, a later date might well be appropriate.

This material tends to come from the upper fill of the fort ditch, late features in the industrial complex and post-Roman and unstratified deposits. Given that most Roman material from civil sites in Scotland is of Antonine date the presence of a quantity of potentially later third/early fourthcentury material at Cramond begs the question of the nature of its final 'Roman' occupation. There seems potentially rather more than can be accounted for by 'Roman patrols or by local native inhabitants through trade' (Holmes 2003, 153). Perhaps not all the casual finds of later Roman coins from the town are modern introductions.

One other vessel is worth noting from this report (Ford 2003, fig 75, no 12). The barrel jar form and organic tempering of this vessel makes it appear to be potentially Saxon. This of course would fit well with the fifth- to sixth-century zoomorphic pin (Holmes 2003, fig 108, no 9) and it may not be coincidental that both come from the area of the former bathhouse, where Ford also reports six bodysherds of possibly early medieval date (Ford 2003, 87).

\subsection{Selective catalogue (including numbered sherds; illus 3)}

\section{Context 7 (upper fill of well 8)}

1 A wide-mouthed jar rimsherd with hooked rim, possibly a Severn Valley Ware form. O01 Dia $26 \mathrm{~cm}, \mathrm{RE}$ $8 \%$, Wt $23 \mathrm{~g}$

2 An oxidized jar in the local micaceous fabric, possibly a BB-derived form, later second-early third century. Exterior slightly burnt. O05 Dia 16cm, RE 10\%, Wt 53g 3 A casserole rimsherd in the cleanish local oxidized fabric O05. Two sherds from the lower fill (context 26) are adjoining parts of the same vessel (as Swan 1992, no 94, early third century). Dia $22 \mathrm{~cm}, \mathrm{RE} 15 \%$, Wt $35 \mathrm{~g}$ 


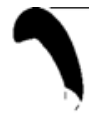

2

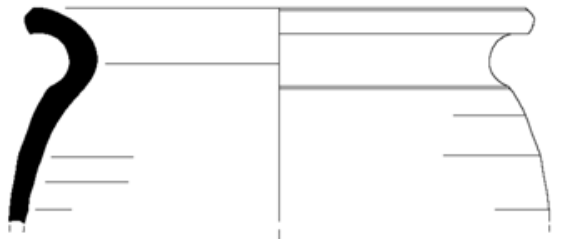

3

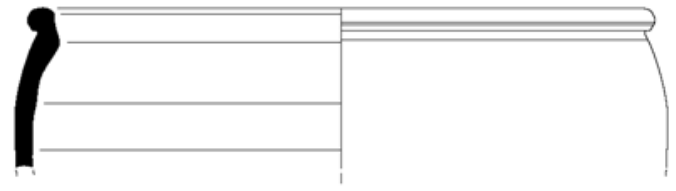

5

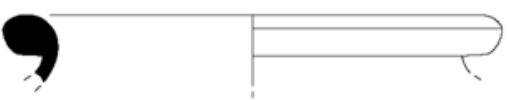

6

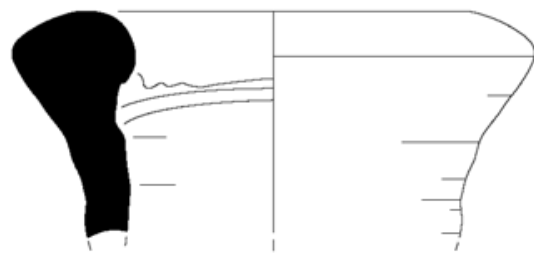

$10 \mathrm{~cm}$

\section{Illus 3 Pottery objects}

4 A micaceous jar rim with fine sand, reduced(?) burnt. R03 Dia $17 \mathrm{~cm}, \mathrm{RE} 11 \%$, Wt $25 \mathrm{~g}$

Context 17 (upper fill of ditch 31)

5 Two Greyware bodysherds with pale core and grey slipped surfaces and a rimsherd in this fabric from a bead-rimmed jar. R01 Dia, 16cm, RE 40\%, Wt 85g

Context 18 (lower fill of ditch 31)

Not illustrated: A Greyware bodysherd, grey slipped, local, decorated with acute lattice and sooted. HadrianicAntonine. R01 Wt 7g

Context 26 (lower fill of well 8)

Two joining casserole rimsherds in the cleanish local oxidized fabric. They cross-join no 2 (context 7). O05 (as Swan 1992, no 94, early third century). Dia $22 \mathrm{~cm}, \mathrm{RE}$ $15 \%$, Wt $35 \mathrm{~g}$

Not illustrated: Two adjoining fragments of the rim, probably of a bowl, in a good orangey-red ware, the gloss of which is orange-red and the fabric orange. The vessel was a product of an East Gaulish workshop, probably located in the Argonne region rather than at Rheinzabern. The vessel was certainly produced in the later second or early third century. If from Argonne, its date of manufacture is most likely to have been in the range $c$ AD 150-200. Dia $c 19, \mathrm{RE}<3 \%$, Wt $1 \mathrm{~g}$

Not illustrated: A small, burnt chip from the fluted base of a mortarium of form Dr 45 which was originally of fairly good quality. Owing to the burnt condition of this fragment and the absence of its gritted interior it is difficult to identify its place of origin. Whether it was produced in Central Gaul or East Gaul, it will be dated after $c$ AD 170, and if an East Gaulish product it may have originated in Trier in the period $c$ AD 170-220/30. Wt $1 \mathrm{~g}$

Not illustrated:A decorated wall sherd and a tiny adjoining chip from a moulded bowl of form Dr 37 from Lezoux in Central Gaul. The bowl represented by this sherd must have been a fairly good product to judge from the fragment of moulded decoration. The sherd displays part of a double, corded festoon (probably Rogers 1974, Type E21) the contents of which are indistinct, but may perhaps include the tips of a leafy motif (as seen on Standfield \& Simpson 1958, plates $158.15 \& 160.46)$. Although merely fragmentary, these decorative motifs may point to the factory of Cinnamus; at any rate a date of manufacture in the earlyto mid-Antonine period may be proposed, perhaps $c \mathrm{AD}$ 140/50-170/80; the general appearance of the sherd would not support a later date of manufacture. Wt $2 \mathrm{~g}$

Context 39 (fill of pit 40)

Not illustrated: A Dr 20 rim. A01 D F Williams identified this with Martin-Kilcher 1987, Beilage 2, no 104, dated AD 210-80. Dia $c 15 \mathrm{~cm}, \mathrm{RE}>4 \%$, Wt $58 \mathrm{~g}$

Context 41 (fill of ditch 42)

6 A Dr 20 rimsherd. A01 D F Williams identified this with Martin-Kilcher 1987, Beilage 2, no 97, dated AD 150210. Dia $16 \mathrm{~cm}$, RE $28 \%$, Wt $240 \mathrm{~g}$ 


\section{Other Finds by Fraser Hunter}

\subsection{Iron objects (including numbered objects; illus 4)}

\subsubsection{Fittings and fastenings}

1 Sub-rectangular binding, tapering in plan to one side, section varying from flat rectangular to slightly planoconvex; one side dented. Timber clamp, perhaps used in carts (cf Newstead; Curle 1911, pl LXV, 1-2, 4). L 132mm, $\mathrm{W} 85 \mathrm{~mm}, \mathrm{H} 34 \mathrm{~mm}, \mathrm{~T} 4 \mathrm{~mm}$. Found with nail. Context 007 (upper fill of Well 008)

2 Collar, subcircular, fragment missing; flat lentoid section. It lacks the stop ridge of a water pipe collar, and its morphology is wrong for a wheel hub rim; probably a clamp for fastening timbers, like (1). H $36 \mathrm{~mm}$, T 7-8.5mm, D $114 \mathrm{~mm}$. Context 015 (fill of Drain 016)

3 Rectangular bar, slightly curved lengthways, ends squared, edges and corners rounded. No indication of fastening method - perhaps intended to slot into two substantial timbers, or perhaps unfinished. L $310 \mathrm{~mm}$, W $47 \mathrm{~mm}, \mathrm{~T} 13 \mathrm{~mm}$. Context 015 (fill of Drain 016)

4 Pivot? Rectangular-sectioned bar $(22 \times 10 \mathrm{~mm})$, one end slightly stepped down on one side before being drawn into a perpendicular rod (D 14mm) with expanded, flattened end. The corners of the other end are elongated into blunt points, apparently intact; one is longitudinal ( $\mathrm{L} 8.5 \mathrm{~mm}, \mathrm{~W}$ $6.5 \mathrm{~mm}$ ), the other (which may be a differential corrosion feature) slighter and perpendicular (L $3 \mathrm{~mm}$, W $5 \mathrm{~mm}$ ). No parallels have been found; the upturned end could function as a pivot with the bar slotted through a supporting frame, but this is speculative. L $142 \mathrm{~mm}, \mathrm{H} 46 \mathrm{~mm}$. Context 027 ( = Context 017, upper fill of Ditch 031)

5 Vessel handle fragment? Circular-section curved rod fragment, rather fine for a ring (with extrapolated D $100 \mathrm{~mm}$ ) and more likely a handle from a vessel. D $6 \mathrm{~mm}$, L 71mm. Context 039 (fill of medieval Pit 040)

6 Looped peg. Rectangular-sectioned bar $(21 \times 7.5 \mathrm{~mm})$, tapering to a point, the upper end thickened (to $21 \mathrm{~mm}$ ) and slightly angled; the top corner is drawn into a subsquare rod (W 12-13mm), curved downwards to form a loop (internally $33 \times 26 \mathrm{~mm}$ ). L $285 \mathrm{~mm}$. Similar examples from previous Cramond excavations were identified as tent pegs (Holmes 2003, 117-18, nos 29-31), but they could equally be tethering pegs (Schalles \& Schreiter 1993, 275, nos 46-7; Manning 1995; Mould 2002, 86-7, no 66). The type is also known at Mumrills (Macdonald \& Curle 1929, fig 124, no 1). Context 028 (fill of Pit 032)

Not illustrated: Handle. Rather irregular rectangularsectioned bar $(20 \times 9 \mathrm{~mm})$, tapering to a rounded bent tip at one end. The other end is flattened into a trapezoidal fastening plate $(63 \times 29 \times 2.5 \mathrm{~mm})$, with two axial perforations (D 7-7.5mm); it is bent and broken, consistent with levering upwards to detach it. L $252 \mathrm{~mm}$. Markedly less corroded than the other ironwork, suggesting it is intrusive. Context 017 (upper fill of Ditch 031)

\subsubsection{Tools and weapons}

7 Chape for a dagger? Sub-circular flat object, hollow, opening damaged but there are hints it was straight. Small surviving copper-alloy fragment at the mouth may come from a scabbard. Must be of two-part construction, although no technical details are visible as wood traces obscure the surface. $25 \times 21 \times 5 \mathrm{~mm}$. Context 017 (upper fill of Ditch 031)

\subsubsection{Unidentified}

Not illustrated: Two flat sheet fragments with surviving straight edge. $25 \times 23 \mathrm{~mm}, 19 \times 15 \mathrm{~mm}$, T c $3.5 \mathrm{~mm}$. Context 007 (upper fill of Pit 008)

Not illustrated: 11 flat sheet fragments, one with a turned edge, two bent through $90^{\circ}$. Probably from a fitting or mount, although insufficient diagnostic features survive for certainty. Context 015 (fill of Drain 016)

Not illustrated: Sheet fragment, no original edges, slightly curved, wood traces in corrosion on one side. $38 \times 31 \times$ 2.5mm. Context 017 (upper fill of Ditch 031)

\subsubsection{Nails}

Thirteen typical square-headed nails were recovered from a range of contexts (Table 2), too few for detailed analysis. Five were intact, with lengths from 41 to $86 \mathrm{~mm}$; the head size of fragmentary ones $(8.5-$ $24 \mathrm{~mm}$ ) implies a wider length range was present. Of the nine reasonably intact nails, three were bent from removal while one was clenched. Two nonstandard nails were also present.

8 Horseshoe nail of 'fiddle-key' type, the tip bent back to hold it on the hoof (for Roman horseshoes see Manning 1976, 31). L $47 \mathrm{~mm}$, head $13 \times 10 \mathrm{~mm}$, shank $6 \mathrm{~mm}$. Context 019 (upper fill of medieval Pit 020)

9 Intact nail embedded in wood remains, with a decorative square head, the edges chamfered; a decorative stud as much as a functional nail. L 54mm, head $9 \mathrm{~mm}$, shank 6.5mm. Context 024 (fill of Pit 025)

\subsubsection{Hobnails and tacks}

Ten hobnails were recovered from a range of contexts (Table 2). Most were domed, but one was conical. In context 007, the upper fill of the well, five hobnails embedded in fragments of iron-impregnated leather imply a shoe sole was deposited; others are corroded together at odd angles, and must have been separate. There was also a larger dome-headed tack.

\subsection{Copper-alloy objects (illus 5)}

Alloy types were determined from surface X-ray fluorescence analysis by Laurianne Robinet. 


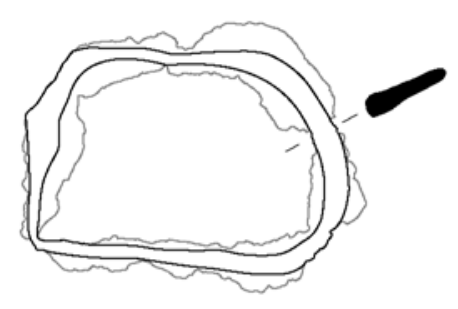

1

2
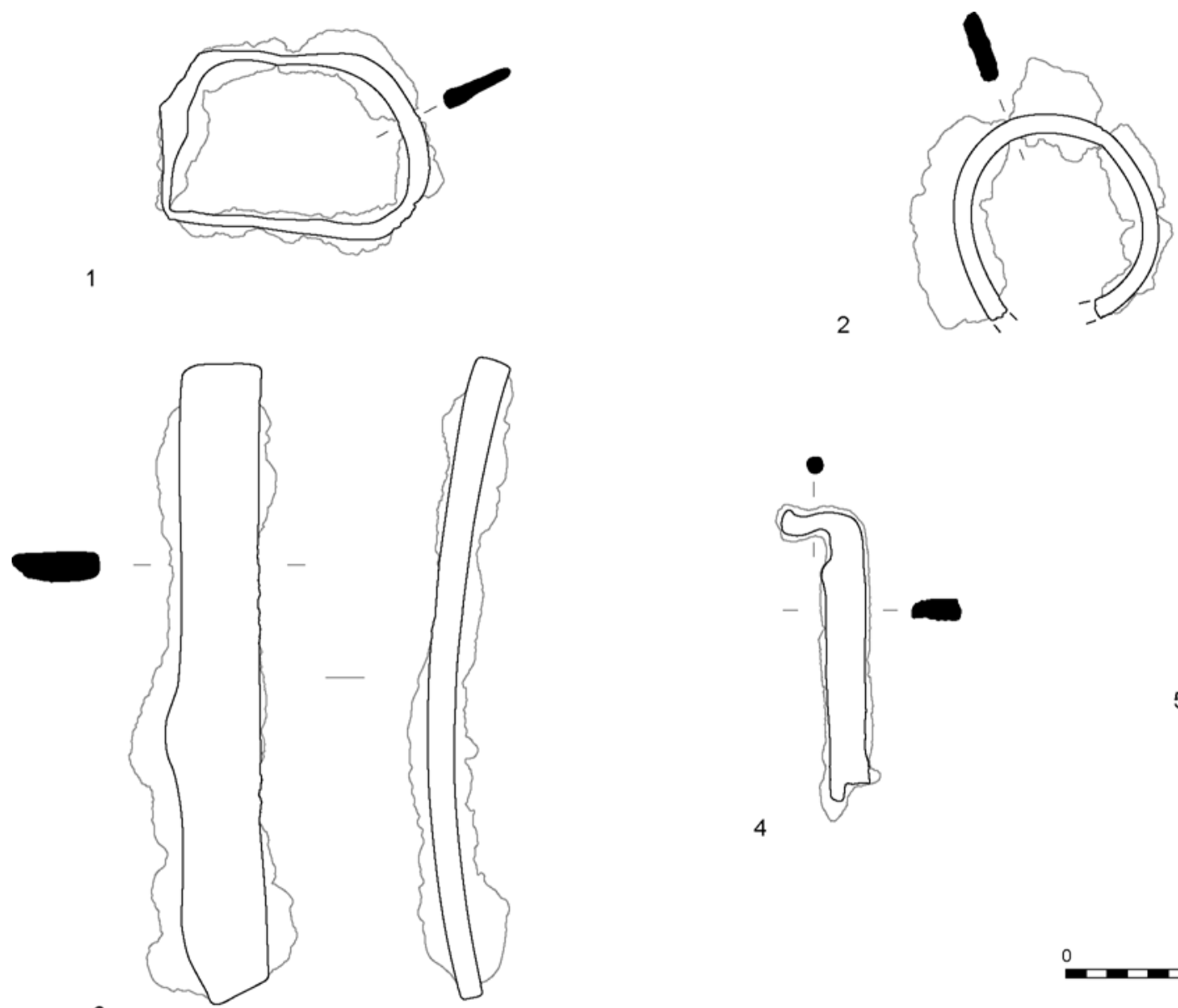

3

4
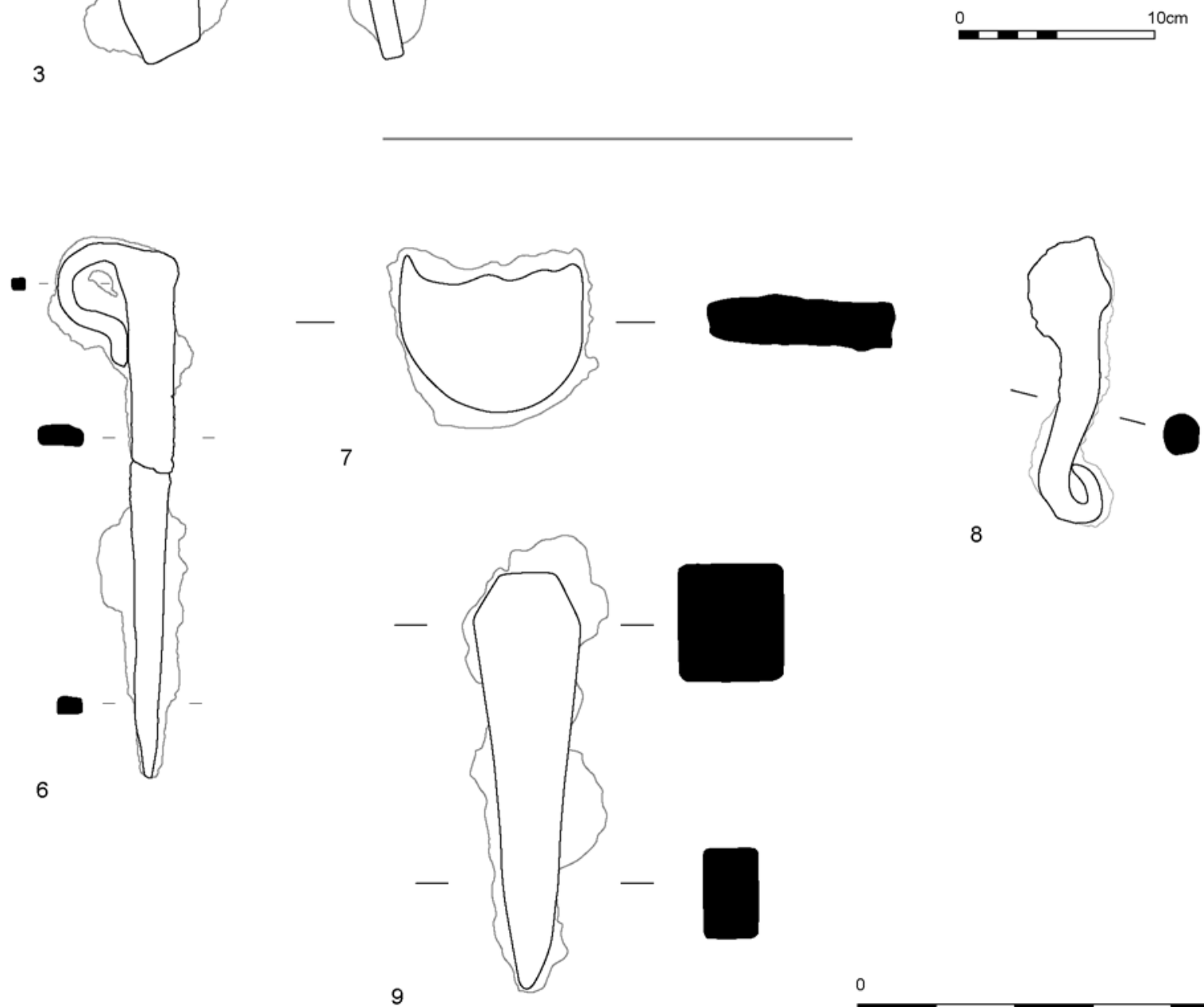

8

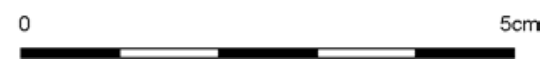

Illus 4 Iron objects

12 

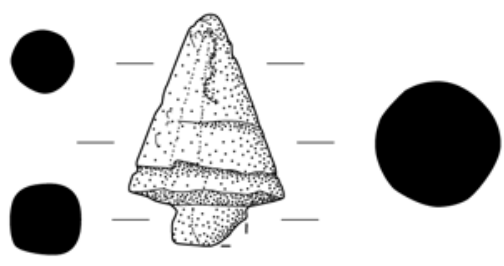

1

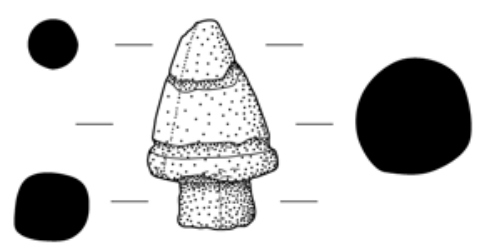

2

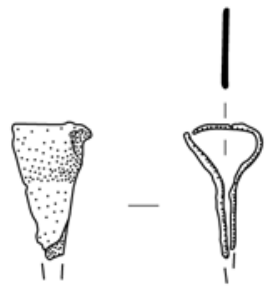

\section{Illus 5 Bronze and lead objects}

1 Conical helmet rivet, cast and hammer-finished, creating a facetted surface; crude decorative grooves at base and midpoint; the short attachment tang (L 4mm, D $7.5 \mathrm{~mm}$ ) is slightly damaged, suggesting it was lost in use. Heavily-leaded bronze. H 24mm, D 16mm. Context 015 (fill of Drain 016)

2 Conical helmet rivet, as (1) but slightly better finished and undamaged. Heavily leaded bronze. Tang L $5 \mathrm{~mm}$, D $7.5 \mathrm{~mm}$. H $21 \mathrm{~mm}, \mathrm{D} 13 \mathrm{~mm}$. Context 017 (upper fill of Ditch 031)

A number of similar rivets, used to fasten brow-peaks and strengthening guards on late second- and thirdcentury helmets (eg Junkelmann 2000, 146, 158), have been found previously at Cramond (Rae \& Rae 1974, 194-5, nos 11-12; Holmes 2003, 105). The late second- to early third-century context of (1) suits this date; (2) is from the upper fill of Antonine Ditch 031, but this infilling may be Commodan-Severan. The heavily leaded alloy would be ideal for casting.

3 Unused rivet of 'paper clip' type, bent over but the arms not folded back. The alloy, a leaded gunmetal, is surprising for a sheet artefact (for which unleaded alloys are normal), suggesting a degree of expediency. Such rivets are known from the Iron Age to the medieval period, and
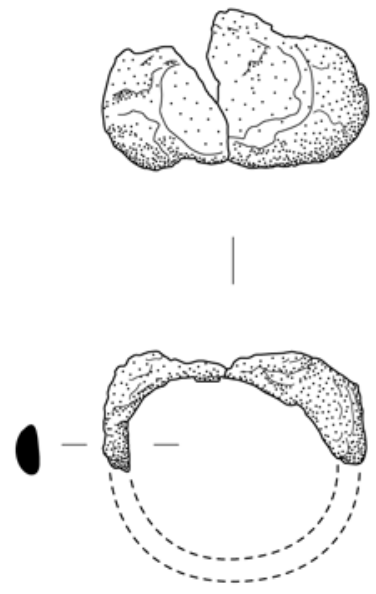

4

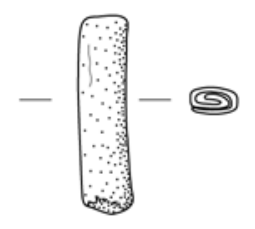

5

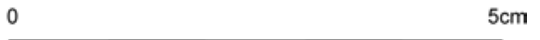

are of no help in dating this isolated feature. $13 \times 8 \times$ $7.5 \mathrm{~mm}$. Context 021 (upper fill of Cut 022)

4 Finger ring; the flat hoop (mostly lost) expands smoothly into a broad oval bezel, intaglio missing. Henig type V, common in the second and third centuries (Henig 1978, 35, 37; Johns 1996, 48). Leaded bronze. Setting $16 \times 12 \mathrm{~mm}$, bezel W $16 \mathrm{~mm}$ (edges lost), external D $25 \mathrm{~mm}$, internal D 20mm, hoop T 2mm. Context 028 (fill of Ppit 032)

\subsubsection{Other/unidentified}

Not illustrated: Unidentified smear of leaded bronze. $6 \times$ $5 \mathrm{~mm}$. Context 002 (topsoil)

Not illustrated: Crumpled and folded sheet fragment. Bronze. $18 \times 13 \times 10 \mathrm{~mm}$. Context 015 (fill of Drain 016) Not illustrated: Unidentified smear, probably a sheet fragment. Low-zinc brass with some lead. $13 \times 5 \mathrm{~mm}$. Context 018 (lower fill of Ditch 031)

\subsection{Lead objects}

5 Small square-sectioned bar made from rolled sheet; function unclear. $20 \times 5 \times 4 \mathrm{~mm}$. Context 007 (upper fill of Well 008) 


\begin{tabular}{|c|c|c|c|c|c|c|c|c|}
\hline 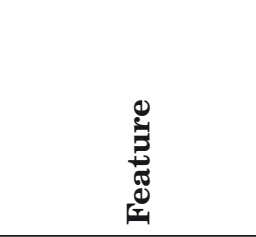 & $\begin{array}{l}\vec{x} \\
\stackrel{0}{0} \\
\dot{0} \\
0\end{array}$ & $\frac{n}{\overparen{\pi}}$ & 星 & 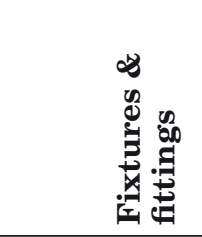 & 赵 & 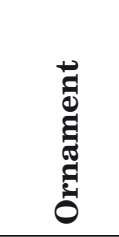 & 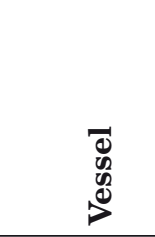 & 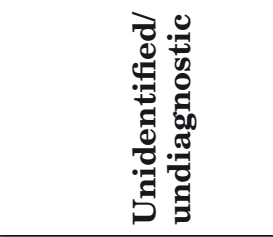 \\
\hline \multicolumn{9}{|l|}{ Antonine } \\
\hline $\begin{array}{l}\text { (006) Ditch cut by } \\
\text { defences }\end{array}$ & $(005)$ & 1 & & & & & & \\
\hline \multirow[t]{2}{*}{$\begin{array}{l}\text { (031) Defensive } \\
\text { ditch }\end{array}$} & $\begin{array}{l}\text { Upper fill } \\
(017)=(027)\end{array}$ & 1 & & $\begin{array}{l}\text { Iron handle } \\
\text { (intrusive?) } \\
\text { Iron pivot(?) }\end{array}$ & $\begin{array}{l}\text { Iron chape, } \\
\text { bronze rivet }\end{array}$ & & & Sheet iron \\
\hline & $\begin{array}{l}\text { Lower fill } \\
(018)\end{array}$ & & & & & & & Sheet bronze \\
\hline \multicolumn{9}{|l|}{ Severan } \\
\hline \multirow[t]{2}{*}{ (008) Well } & $\begin{array}{l}\text { Upper fill } \\
(007)\end{array}$ & 7 & 7 & Iron binding & & & glass & $\begin{array}{l}\text { Sheet iron } \\
\text { lead bar }\end{array}$ \\
\hline & $\begin{array}{l}\text { Lower fill } \\
(026)\end{array}$ & 1 & & & & & & Melted lead sheet \\
\hline (013) Drain & Fill (015) & 1 & 4 & $\begin{array}{l}\text { Iron collar } \\
\text { Iron bar }\end{array}$ & $\begin{array}{l}\text { Copper- } \\
\text { alloy rivet }\end{array}$ & & & $\begin{array}{l}\text { Sheet iron } \\
\text { fragments, bronze } \\
\text { sheet fragment }\end{array}$ \\
\hline (020) Sump & $\begin{array}{l}\text { Upper fill } \\
(019)\end{array}$ & $\begin{array}{l}\text { Horse } \\
\text { shoe }\end{array}$ & & & & & & \\
\hline (032) Pit & Fill (028) & & & Iron peg & & $\begin{array}{l}\text { Bronze } \\
\text { ring }\end{array}$ & & \\
\hline \multicolumn{9}{|l|}{ Medieval } \\
\hline (040) Pit & Fill (039) & & & & & & $\begin{array}{l}\text { Iron } \\
\text { handle(?) }\end{array}$ & \\
\hline \multicolumn{9}{|l|}{ Undated } \\
\hline & Layer 2 & 1 & & & & & & Bronze fragment \\
\hline (022) Pit & $\begin{array}{l}\text { Upper fill } \\
(021)\end{array}$ & & & Alloy rivet & & & & \\
\hline (025) Pit & Fill (024) & $\begin{array}{l}1+1 \\
\text { decor }\end{array}$ & & & & & & \\
\hline
\end{tabular}

Not illustrated: Flat amorphous melted sheet. The regularity of the pattern on one side suggests it formed against an organic surface, perhaps basketry. Because lead melts easily, this is likely to be accidental rather than evidence of lead-working. $63 \times 30 \times 9 \mathrm{~mm}$. Context 026 (lower fill of Pit 008)

\subsection{Glass}

Not illustrated: Plain base sherd from a square glass bottle, one of the most common types (Price \& Cottam 1998, 194-8). $56.5 \times 36.5 \times 7 \mathrm{~mm}$. Context 007 (upper fill of Well 008)

\subsection{Discussion}

Table 2 divides the assemblage by context and function. It is dominated by everyday items such as nails and fittings, with a little militaria (the helmet rivets and possible dagger chape) and a few other items (notably the finger ring). Some of the fittings imply the presence of substantial wooden constructions, perhaps carts. It is striking that the looped peg and helmet rivets, unusual or unique in a Scottish context, are paralleled from previous Cramond excavations. This arises at least in part from the date, the helmet rivets for instance being a post-Antonine type. Most of the finds come from the upper fills of Well 008, Ditch 031 or Drain 013, and represent material deposited when the area was being cleared. A similar phenomenon was noted in the industrial area to the south-east, where an extensive destruction deposit across the site contained many artefacts (Holmes 2003, 33). 


\section{Plant Remains by Mhairi Hastie}

\subsection{Methodology}

\subsubsection{Sample strategy and processing}

Soil samples for environmental analysis were taken from a representative selection of all ditch, pit and drain features. Seventeen samples were subjected to a system of flotation and wet-sieving in a Sirafstyle flotation tank. The floating debris was collected in a $250-\mu \mathrm{m}$ sieve and, once dry, scanned using a binocular microscope. Any material remaining in the flotation tank was wet-sieved through a $1 \mathrm{~mm}$ mesh and air-dried. This was then sorted by eye and any material of archaeological significance removed.

\subsubsection{Sample assessment}

The archaeobotanical evidence was restricted to charred plant remains as ground conditions on the site were not suitable for preservation of organic remains by waterlogging. The majority of samples contained low concentrations of carbonized cereal grains, weed seeds and charcoal. In addition, a number of samples contained the carbonized remains of legume seeds.

The following report concentrates on the botanical element of the samples. Identifications were made with reference to the modern comparative collection of Headland Archaeology and seed atlases (Berggren 1969; Berggren 1981). Botanical nomenclature generally follows that of the Flora Europaea (Tutin et al. 1964-80).

\subsection{Results}

\subsubsection{Distribution}

Carbonized plant remains were present in the majority of features excavated, albeit in low quantities. Plant assemblages were dominated by cereal grains, primarily wheat and barley. Some were in good condition but much was abraded. The highest concentration of cereal remains (over 300 identifiable grains) was recovered from context 019, the upper fill of medieval Pit 020.

\subsubsection{Composition}

Cereal and chaff remains Grains of wheat (Triticum $\mathrm{sp}$ ) and hulled barley (Hordeum vulgare) were the most frequently encountered elements. Both bread/club wheat (T. aestivo-compactum) and spelt (T. spelta) were identified. One barley rachis internode was recovered from context 019. Grains of oat were also present in five of the samples. The lemma and palaea remained attached to one oat grain recovered, from context 039 (fill of Pit 040), and this was identified as being black oat (Avena strigosa).

Wild taxa Small quantities of seeds and fruits of wild taxa were recovered from a number of the samples. The taxa present are typical ruderal/ segetal species of Northern Britain, ie species of agricultural fields and disturbed ground, including knotgrass (Polygonum sp), buttercup (Ranunculus $\mathrm{sp}$ ) and dock (Rumex sp). High concentrations of seeds of vetch/tare (Vicia/Lathyrus), indicative of grasslands, were also recovered from contexts 007 and 026, the deposits in Well 008.

Other economic species A number of charred horse/broad bean seeds (Vicia faba) were recovered from the two fills of Well 008 (contexts 007 and 026).

\subsection{Discussion}

\subsubsection{Roman features}

Low concentrations of carbonized plant remains were recovered from Ditches 031, 030 and 044, Well 008 and Drain 016. The plant remains consisted of a mixture of cereal grain, weed seeds and an assemblage of legume seeds including horse bean. The cereal remains included spelt, bread/club wheat, hulled barley and oat. Evidence from other Roman military and non-military sites across Britain indicate that these cereal species were being cultivated during the Roman period (Boyd 1988; Dickson 1989; Huntley \& Stalisbrass 1995); the plant assemblage from Cramond is therefore typical of this period.

Low quantities of abraded grain were recovered from context 038, the upper fill of the Antonine defensive Ditch 031. The presence of cereal remains within the upper fill could indicate that some domestic activity was being carried out whilst the ditch was still partially open.

Contexts 007 and 026, the deposits within Well 008, contained low levels of abraded cereal grain and a small assemblage of seeds of horse/broad bean (Vicia faba). The same deposit also contained a large number of carbonized and highly abraded seeds of vetch/tare (Vicia/Lathyrus). Vetch/tare seeds were the dominant plant remains recovered from the well, with over 120 identifiable seeds present. Both species are common elements of grasslands and arable fields. 
Legume seeds are rarely recovered from Scottish Roman sites, the principal evidence for their use coming from samples taken from a waterlogged ditch fill at Bearsden (Dickson 1989). The waterlogged remains from that site included seeds of pulses, legumes and herbs, indicating that these food types were being transported across the Roman Empire. Documentary sources also indicate that beans and lentils were considered an important part of the Roman army diet. Written records indicate that horse/broad beans were either made into bean meal that was used in the making of bread, or cooked into a pottage that was fortified with pieces of meat or fish (Alcock 2001). There is little evidence, however, to indicate how the beans were prepared once harvested.

It is most likely that the carbonized horse beans present in the well fill at Cramond are the remnants of food charred either during food preparation or drying/ roasting. Unlike grain, it is not necessary for beans to be dried prior to processing and they are therefore less likely to become charred. However, beans could have been dried in order to allow long-term storage or may have been roasted prior to consumption or milling. For instance, beans were recovered from a Roman drier at Odell villa, Bedfordshire, suggesting that the beans were being deliberately dried (Alcock 2001). The vetch/tare seeds recovered with the beans may be the remains of weed seeds that were contaminants of the bean crop.

\subsubsection{Medieval features}

Carbonized plant remains were recovered from medieval Pits 020 and 040. The upper fill of Pit
020 (context 019) contained the largest single plant assemblage recovered from the whole site, with over 600 grains recovered. The most abundant element was cereal grain, with bread/club wheat, hulled barley and oat present. The quantity of grain is such that it seems likely that some sort of accidental burning occurred, either during corn-drying or through conflagration of a store, and the spoiled corn was dumped into the pit.

The mixture of cereals present is typical of Scottish medieval assemblages but the high percentage of bread/club wheat compared to oat and hulled barley is unusual. Hulled barley and oat were the more commonly cultivated cereals during this period in Scotland. The high proportion of bread/club wheat may be a reflection of the close proximity of the site to East Lothian and Fife where bread wheat was more readily cultivated and would in turn suggest a possible high status for the site.

\subsubsection{Features of unknown date}

Carbonized plant remains were recovered from two features of unknown date, Pit 025 and Deposit 017. In both cases the amount of plant remains recovered was very sparse. The assemblage was predominantly cereal grain, with both wheat and barley present. This concentration of charred remains would be consistent with low-levels of re-worked material from the topsoil being incorporated into negative features and there is little evidence to suggest that the charred remains are related to the use of these features. 


\section{Discussion}

The most significant result of the Kirk Hall excavation is the identification of a possible third defensive ditch outside the fort at Cramond. The ditch was turned to flank the road running towards the fort, and was presumably looped together with the two inner ditches described by Holmes. No evidence for a third ditch has been encountered in previous excavations at Cramond, but neither have they provided any grounds for ruling out its existence. The excavations at 23 Cramond Glebe Road (DES 1995), outside the south gate of the fort, found no evidence for either the second or third ditches in their projected locations, but the area excavated was perhaps too small for this to count as evidence of their absence. In any case, it is possible that the ditches were not present on all sides of the fort. The evidence for the road on the Kirk Hall site, consisting of an undated cobbled surface and possible roadside ditches, is somewhat circumstantial but gains support from what is known of its route from previous excavations. These features are thought to be part of the original Antonine construction, as the few finds recovered from them included no Severan material.

The presence of earlier Roman ditches, apparently unrelated to the fort and cut by the Antonine ditches, raises some interesting possibilities. A ditch on a similar alignment was excavated at 23 Cramond Glebe Road, where it was suggested that it might belong to an earlier fort, so the possibility of a Flavian fort at Cramond cannot be discounted; alternatively, the Antonine fort may have been preceded by one or more temporary camps in the vicinity. The small size of the features at the Kirk Hall site is, however, difficult to reconcile with either interpretation.

The history of the fort at Cramond as proposed by Rae \& Rae envisages two phases of Antonine construction, followed by a period of abandonment and reoccupation during the Severan invasion (Rae \& Rae 1974). This interpretation has been questioned by Holmes, who points to the lack of evidence for an intervening phase of demolition which might be expected if the Roman army had withdrawn from Cramond as part of the general retreat from the Antonine frontier around AD 160 (Holmes 2003, 147-51). Holmes suggests that Cramond might have been retained as an outpost during the later second century, which would explain the apparent fact that the Antonine buildings in the interior of the fort survived - at least in part - to be repaired and reused during the Severan occupation, when Cramond would have functioned as a support base for military operations further to the north. The presence of pottery types which suggest, without proving, continued occupation in the later second century is also cited by Holmes in support of this view. The evidence for Severan occupation of the fort itself is problematic, however, as so few finds of definite Severan date were recovered from the Raes' excavations in the interior of the fort; the case for the Severan phase rests mainly on two coins of Julia Domna sealed by the floors of buildings within the praetentura. With this exception, it can be argued that the fort itself was not reoccupied in any substantial way during the Severan invasion, despite the activity within the annexe to the east.

A change in the use of the site at Cramond between the Antonine and Severan occupations is suggested by the fact that the outer defensive ditch and roadside ditches excavated at the Kirk Hall site went out of use and were allowed to silt up, and were then slighted by the drain, well and pits which cut across them. These later features, backfilled in the early third century, appear to represent the encroachment of settlement and/or industrial activity on the outer defences of the fort, which had ceased to be maintained. This is consistent with the lack of evidence for Severan re-cutting in the two inner defensive ditches (Holmes 2003, 7-8). The construction of what seems to have been an open drain, cutting across the line of the road, also suggests that the gateway of the fort was no longer in use. Even if the fort was occupied at this date, strong defences were evidently no longer deemed necessary in this location. This might reflect a changed role for Cramond as a supply base, situated within the large defended annexe to the east of the fort. The metalwork associated with the early third-century backfilling of the later features confirms the military associations of this phase. Charred cereal grains and legumes also indicate that food was being processed on the site; an assemblage of horse beans associated with vetch/tare seeds in the fill of the well appears to derive from drying or roasting of a bean crop.

A reappraisal of the pottery from earlier investigations at Cramond indicates continued activity, with Roman connections at Cramond in the later third century. A late third- or early fourth-century date can be definitely assigned to several sherds published previously (Holmes 2003), while many others previously described as Severan are more likely to be later. Most of the forts in Scotland are thought to have been abandoned rapidly after the death of Severus and the subsequent withdrawal of the army, but the later history of Cramond may differ in this respect. Whether the later material represents a continuing, if intermittent, military presence, or some other form of occupation, perhaps by a local potentate with Roman connections, remains an open question. 


\section{Acknowledgements}

The excavation and post-excavation work was funded by the Cramond Kirk Millennium Committee and Historic Scotland. The excavation was carried out by Magnar Dalland, with the assistance of Jo Dawson, and the author benefited from the advice and assistance of Magnar Dalland in preparing this report. Gretel Evans of AOC Archaeology Group carried out the conservation of the metalwork, and Fraser Hunter is also grateful to Laurianne Robinet for XRF analyses and Bill Manning for comments on some of the more troublesome pieces. The illustrations were produced by Tom Small. Project management was by Colm Moloney and Chris Lowe. The advice of John Lawson in researching the background to the site was appreciated, and John Gooder kindly provided information on the AOC excavations at the Cramond Campus site. 


\section{References}

Alcock, J P 2001 Food in Roman Britain.Tempus, Stroud.

Berggren, G 1969 Atlas of Seeds and Small Fruits of North-west European Plant Species with Morphological Descriptions: Part 2 Cyperaceae. Berlings, Halmstad, Sweden.

Berggren, G 1981 Atlas of Seeds and Small Fruits of North-west European Plant Species with Morphological Descriptions: Part 3 SalicaceaeCruciferae. Berlings, Halmstad, Sweden.

Bidwell, P T \& Speak, S 1994 Excavation at South Shields Roman Fort, Vol 1. Newcastle upon Tyne.

Boyd, W 1988 'Cereals in Scottish antiquity', Circaea 5(2), 101-10.

Curle, J 1911 A Roman Frontier Post and Its People. Maclehose, Glasgow.

Dalland, M. 2001 An Archaeological Excavation of a Proposed Building Extension to Cramond Kirk Hall, Cramond, City of Edinburgh. Unpublished report by Headland Archaeology, Edinburgh.

DES 1995 '23 Cramond Glebe Road', Discovery Excav Scot 1995, 53.

Dickson, C 1989 'The Roman army diet in Britain and Germany', Archäobotanik Dissertationes Botanicae 133, 135-54.

Evans, J 2001 'Material approaches to the identification of different Romano-British site types', in James, S \& Millett, M J (eds) Britons and Romans: Advancing an Archaeological Agenda. Council for British Archaeology, York.

Evans, J 2002 'Pottery from Thornborough Farm', in Wilson, P R Cataractonium: Roman Catterick and its Hinterland, Excavations and Research, 479-96. London (= CBA Res Rep 128).

Evans, J forthcoming 'Report on the pottery from Doune Roman fort'.

Ford, B 2003 'Coarse pottery', in Holmes 2003, 58-86.

Gooder, J 2000 'Cramond campus', Discovery Excav Scot 2000, 33.

Henig, M 1978 A Corpus of Roman Engraved Gemstones from British Sites. Oxford (= Brit Archaeol Rep, Brit Ser 8).

Holmes, N 2003 Excavations of Roman Sites at Cramond, Edinburgh. Edinburgh (= Soc Antiq Scotland monogr ser 23).

Hoy, C 1990 'Cramond', Discovery Excav Scot 1990, 29.

Hunter, F 2004 'Roman Britain in 2003: sites explored: Scotland', Britannia 35, 265-71.

Huntley, J P \& Stallibrass, S 1995 Plant and Vertebrate Remains from Archaeological Sites in Northern England: Data Reviews and Future
Directions. Research Report 4, Architectural and Archaeological Society of Durham and Northumberland.

Johns, C 1996 The Jewellery of Roman Britain. UCL Press, London.

Junkelmann, M 2000 Römische Helme (Band VIII Sammlung Axel Guttmann. Verlag Sammlung Guttmann \& von Zabern, Berlin.

Macdonald, G \& Curle, A O 1929 'The Roman fort at Mumrills, near Falkirk', Proc Soc Antiq Scot 63 (1928-9), 396-575.

Manning, W H 1976 Catalogue of Romano-British Ironwork in the Museum of Antiquities, Newcastle upon Tyne. Dept of Archaeology, University of Newcastle upon Tyne, Newcastle.

Manning, W H 1995 'Miscellaneous', in Manning, W H, Price, J \& Webster, J Report on the Excavations at Usk 1965-1976: the Roman Small Finds, 45. University of Wales Press, Cardiff.

Martin-Kilcher, S 1987 Die Romischen Amphoren aus Augst und Kaiseraugst, Bern.

Mould, Q 2002 'Iron objects from Catterick Bypass (Site 433)', in Wilson, $\mathrm{P} \mathrm{R}$ Cataractonium: Roman Catterick and its Hinterland. Excavations and Research, 1958-1997, part II, 82-99. London (= CBA Res Rep 129).

Price, J \& Cottam, S 1998 Romano-British Glass Vessels: a Handbook. Council for British Archaeology, York (Practical Handbooks in Archaeology 14).

Rae, A \& Rae, V 1974 'The Roman fort at Cramond, Edinburgh. Excavations 1954-66', Britannia 5, 163-223.

Rogers, G B 1974 'Poteries sigillees de la Gaule centrale, I; les motifs non figures', Gallia Supplement 28.

Schalles, H-J \& Schreiter, C (eds) 1993 Geschichte aus dem Kies: Neue Funde aus dem Alten Rhein bei Xanten. Rheinland-Verlag, Köln.

Stanfield, J A \& Simpson, G 1958 Central Gaulish Potters, Oxford (French edition, 1990, Les potiers de la Gaule centrale, Revue Archaeologique Sites 37).

Swan, V G 1992 'Legio VI and its Men: African Legionaries in Britain', J Roman Pottery Studies $5,1-34$.

Terry, J 1998 An Archaeological Evaluation Report for a Proposed Building Extension to Cramond Kirk Hall, Cramond, City of Edinburgh 1998. Unpublished report by Headland Archaeology, Edinburgh.

Tutin, T G, Heywood, V H, Burges, N A, Valentine, D H, Walters, S M \& Webb, D A 1964-80 Flora Europaea. Cambridge University Press, Cambridge. 